\title{
Relationship between food consumption of pregnant women and birth weight of newborns
}

\section{Relación entre el consumo de alimentos de gestantes y el peso al nacer de los recién nacidos}

\begin{abstract}
The aim of this study was to investigate the relationship between food consumption of 99 pregnant women aged 16-44 years who gave birth at a maternity hospital in Rio de Janeiro and newborn birth weight. Maternal consumption of unprocessed or minimally processed and ultra-processed foods was evaluated through the Food Consumption Markers Form. For ultra-processed foods, most pregnant women regularly consumed sweets $(73.7 \%)$, soft drinks $(71.7 \%)$, sausages $(65.7 \%)$, salted crackers $(63.6 \%)$ and fried foods (55.6\%). Among unprocessed or minimally processed foods, most pregnant women consumed beans $(85.9 \%)$ and milk or yogurt $(60.6 \%)$, while less than half consumed fruits $(44.4 \%)$, raw vegetables $(28.3 \%)$ and cooked vegetables (27.3\%) regularly. Among newborns, $13.5 \%$ presented low birth weight. There was a significant relationship between consumption of sausages $(p=0.02)$ and sweets $(p=0.04)$ by pregnant women and low birth weight of newborns. Maternal consumption of sausages increased the odds of newborn low birth weight (OR 1.46, 95\% Cl 1.02-2.10).
\end{abstract}

Keywords: Food consumption; Low birth weight; Pregnant; Unprocessed foods; Ultra-processed foods.

\section{RESUMEN}

El objetivo fue investigar la relación entre el consumo de alimentos de 99 gestantes de 16 a 44 años, atendidas en una maternidad de Río de Janeiro, y el peso al nacer de los recién nacidos. El consumo materno de alimentos no procesados o mínimamente procesados y ultraprocesados se evaluó a través del Formulario de Marcadores de Consumo de Alimentos. Se observó que entre los recién nacidos, 13,5\% tenían bajo peso al nacer. La evaluación del consumo de alimentos maternos mostró que, entre los alimentos ultraprocesados, la mayoría de las gestantes consumieron regularmente dulces $(73,7 \%)$, gaseosas $(71,7 \%)$, embutidos $(65,7 \%)$, galletas saladas $(63,6 \%)$ y frituras $(55,6 \%)$. Entre los alimentos no procesados o mínimamente procesados, la mayoría de las gestantes consumieron frijoles $(85,9 \%)$ y leche o yogur $(60,6 \%)$, mientras que menos de la mitad utilizaba frutas $(44,4 \%)$, verduras crudas $(28,3 \%)$ y
Beatriz Rodrigues ${ }^{1 *}$, Vilma Azeredo ${ }^{2}$, Alexandra Silva².

1. Programa de Pós-graduação em Saúde Materno-Infantil, Faculdade de
Medicina, Universidade Federal Fluminense, Niterói, RJ, Brasil
2. Departamento de Nutrição e Dietética, Faculdade de Nutrição Emília de Jesus Ferreiro, Universidade Federal Fluminense, Niterói, RI, Brasil

*Corresponding author: Beatriz Rodrigues. Faculdade de Nutrição Emília de Jesus Ferreiro, Universidade Federal Fluminense. Rua Mário Santos Braga, n. 30, 4 andar. Valonguinho, Centro. Niterói, RJ. CEP 24020-140.

Telefone: (21) 2629-9846. E-mail: beatriz.bber@gmail.com

Este trabajo fue recibido el 21 de enero de 2019. Aceptado con modificaciones: 26 de abril de 2019. Aceptado para ser publicado: 13 de agosto de 2019.

verduras cocidas $(27,3 \%)$ regularmente. Se observó una relación significativa entre el consumo de embutidos ( $p=$ $0,02)$ y dulces $(p=0,04)$ en gestantes con el bajo peso al nacer. El consumo materno de embutidos aumenta la probabilidad de que los recién nacidos presenten bajo peso al nacer, a medida que aumenta su consumo (OR 1,46, IC 95\% 1,02-2,10).

Palabras clave: Alimentos no procesados; Alimentos ultraprocesados; Bajo peso al nacer; Consumo de alimento; Gestante.

\section{INTRODUCTION}

The diet of the world's population is currently characterized by high consumption of ultra-processed 
foods and low consumption of unprocessed or minimally processed foods ${ }^{1,2,3}$. Ultra-processed foods have high caloric density and low nutritional quality and consumption is related to nutritional deficiencies, obesity, diabetes, arterial hypertension and other diseases ${ }^{4,5}$.

Inadequate diet during pregnancy may imply nutritional risk to newborns, favoring low birth weight (LBW) and negatively affecting growth and development ${ }^{6,7,8,9}$. Birth weight is an important public health indicator, as it reflects maternal health conditions and the quality of prenatal care ${ }^{10}$.

According to the United Nations Children's Fund (UNICEF) ${ }^{11}$, in 2000, the prevalence of LBW in developed countries was around $7.0 \%$ and $10.0 \%$ in Latin America. LBW contributes to negative outcomes in infant health, such as developmental deficits, behavioral disorders and vulnerability to infectious diseases, favoring morbidity and mortality in the first year of life ${ }^{12,13}$, and increasing the chances of future chronic diseases ${ }^{8,10}$.

It is known that unprocessed and minimally processed foods, such as fruits and vegetables have more vitamins, minerals, fibers and compounds with antioxidant and antiinflammatory properties compared to ultra-processed foods. Therefore, diet characterized. by the frequent consumption of unprocessed foods is considered a protective factor for the occurrence of chronic diseases, nutritional deficiencies and other adverse health conditions ${ }^{1}$.

There are few studies that have evaluated maternal diet from the point of view of the consumption of unprocessed or minimally processed foods and ultra-processed foods and its influence on fetal growth, especially on LBW. Thus, the main aim of this study was to investigate the relationship between food consumption of pregnant women seeking care at the "Herculano Pinheiro" Maternity Hospital and the birth weight of their newborns.

\section{METHODOLOGY}

We conducted a cross-sectional analytical study with 99 pregnant women aged 16-44 years who received care at the Herculano Pinheiro Maternity Hospital (HPHM) between July and September 2016. The maternity hospital, located in the northern region of the municipality of Rio de Janeiro, is a reference hospital for the follow-up of low-risk pregnant women. Sampling was conducted for convenience. Women were approached after giving birth and received explanations about the study.

Volunteers accounted for $12 \%$ of women receiving care at this maternity hospital. The sample was calculated considering the average number of births in 24 hours at the hospital with a margin of error of $5 \%$ and $95 \%$ confidence interval $(95 \% \mathrm{Cl})$. The calculated total sample was 83 women and, considering a potential $20 \%$ loss, the number stipulated for this study was 99 women.

Women hospitalized at the maternity hospital who gave birth within 24 hours of admission were eligible to participate. After being informed of the research objectives and procedures, and with their agreement to voluntarily participate in the study, they provided signed informed consent. Women who were hospitalized for more than 24 hours were excluded, that way feeding provided at the maternity ward would not interfere with the evaluation of diet. Other exclusion criteria used were: twin pregnancy; abortion; previous diagnosis of diseases such as hypertension and diabetes; presence of obstetric hemorrhagic and infectious complications.

Maternal data were collected through medical record, prenatal care card of pregnant women and a general information questionnaire. Age, marital status, schooling, per capita income, number of pregnancies, pre-gestational weight, final gestational weight, gestational weight gain, gestational age and type of delivery performed in the maternity ward were analyzed.

Pregnant women were classified as adolescents or adults according to World Health Organization ${ }^{14}$. Pre-gestational weight was the weight recorded by the woman at the first prenatal visit. Final gestational weight was the last weight recorded in prenatal care card of pregnant women. Per capita income was calculated based on the total family income, measured by the sum of the monthly income of all family members divided by the number of residents in the household.

Birth weight of newborns was collected and classified according to UNICEF ${ }^{11}$ : extreme low birth weight (weight less than 1,000 g); very low birth weight (weight less than 1,500 g); low birth weight (weight less than 2,500 g); insufficient weight (weight between 2,500 g and 2,999 g); normal or suitable weight (weight between 3,000 g and 3,999 g); overweight (weight greater than or equal to 4,000 g).

Maternal food consumption was evaluated through the Food Consumption Markers Form of the Food and Nutrition Surveillance System ${ }^{15}$, validated for children over five years of age, adults, older adults and pregnant women. This form is used to identify the consumption pattern of so-called "food consumption markers", which are indicative of healthy and unhealthy eating practices.

The form has ten food groups: Group 1) Raw vegetables (lettuce, tomato, carrot, cucumber, cabbage); Group 2) Cooked vegetables (cabbage, squash, chayote, broccoli, spinach, not including potato and cassava); Group 3) Fresh fruit or fruit salad; Group 4) Milk or yogurt; Group 5) Beans; Group 6) French fries, potato chips, and fried snacks such as chicken drumstick, meat ball, pastry, etc.; Group 7) Burgers and sausage (sausage, mortadella, salami, ham, etc.); Group 8) Crackers / Salty crackers or packaged snacks; Group 9) Sweet or stuffed biscuits, sweets, candies and chocolates (in bar or candy); Group 10) Soft drinks (not including diet or light soft drinks). Groups 1 to 5 are considered "markers of healthy food consumption" and Groups 6 to 10 "markers of unhealthy food consumption". To determine the food consumption frequency in the last seven days, eight answer options were provided: "I have not eaten in the last seven days"; "One day in the last seven days"; "Two days in the last seven days"; "Three days in the last seven days"; "Four 
days in the last seven days"; "Five days in the last seven days"; "Six days in the last seven days" and "All days in the last seven days"15.

Using the NOVA Food Classification ${ }^{4}$ as a reference, food groups were classified according to the degree of processing, being divided into: a) unprocessed or minimally processed foods; b) processed culinary ingredients; c) processed foods; d) ultra-processed foods. Groups 1 to 5 were classified as unprocessed or minimally processed foods and Groups 6 to 10 as ultra-processed foods.

The $75^{\text {th }}$ percentile of consumption of each food or food group studied was adopted as a cutoff point for regular consumption of unprocessed or minimally processed foods. For the regular consumption of ultra-processed foods, the 25th percentile of consumption of each food or food group was adopted ${ }^{16}$.

For statistical analysis, collected data were typed and consolidated using SPSS / PC software, version 17.0. Descriptive statistics were used to present the results by arithmetic mean $(x)$, standard deviation $(S D)$, median (MD), minimum and maximum values and frequencies. The Kolmogorov-Smirnov test was used to verify if maternal variables age, per capita income, pre-gestational weight, final gestational weight, gestational weight gain and food consumption followed the normality pattern. Variables with non-normal distribution were presented as median and interquartile range and non-parametric tests were used for these variables.

The chi-square test was used to verify possible relationship between birth weight and maternal age, number of pregnancies and gestational weight gain. The Mann-Whitney test was used to evaluate the relationship between maternal food intake and maternal age. The Kruskal-Wallis test and the Dunn post-test were applied to assess the relationship between maternal food consumption and birth weight.

Analyses of correlation between maternal food consumption and child data were conducted. Pearson's correlation was used for variables with normal distribution and Spearman's for non-normal variables. Significance level of $5 \%$ was adopted in all analyses.
For multivariate analysis, binary logistic regression procedures were used, whose dependent variable was categorized by the classification of low birth weight (1 - low birth weight, 0 - no low birth weight), with the no low birth weight category considered as a reference. Among the set of variables for food consumption, logistic regression was performed adjusted for the following variables: age, per capita income, pre-gestational weight, gestational weight gain, number of pregnancies and type of delivery. Odds Ratio (OR), 95\% confidence intervals $(95 \% \mathrm{Cl})$ and $\mathrm{p}$-values for food consumption variables were estimated.

The present study was submitted and approved by the Ethics Research Committee of the Municipal Health Secretariat of Rio de Janeiro under number 47887915.5.0000.5279, in accordance with the ethical principles contained in Resolution 466/12 of the National Health Council.

\section{RESULTS}

The majority of participants were single (79.8\%), adults $(67.7 \%)$, multiparous $(62.6 \%)$ and had incomplete high school $(38.8 \%)$. The majority of birth were with a normal delivery $(76.8 \%)$. On average, $38.4 \%$ of women gained between 8.0 and $11.5 \mathrm{~kg} ; 44.2 \%$ gained more than $11.5 \mathrm{~kg}$ by the end of pregnancy. Among newborns, the majority presented normal birth weight (57.3\%). However, $27.1 \%$ showed insufficient weight and $13.5 \%$ LBW. Only $2.1 \%$ of newborns were overweight.

Table 1 shows data on pregnant women and birth weight of newborns. It was observed that the mean age of participants was $24.9 \pm 6.5$ years. Mean gestational age was $39.4 \pm 1.2$ weeks, indicating that, on average, infants were not premature. Among newborns, mean birth weight was $3082.0 \pm 559.0 \mathrm{~g}$.

The average per capita income was $U \$ 87.00 \pm 69.60$. Around $8 \%$ of participants did not know how to report family income. The maximum per capita income observed was U\$326.20.

Correlation analysis showed a positive association between gestational weight gain and newborn birth weight $(r=0.22, p=0.04)$.

Table 1. Characteristics of pregnant women and newborn birth weight.

\begin{tabular}{|lrrrrrr|}
\hline Variables & N & $\overline{\mathbf{X}}{ }^{\mathbf{1}}$ & SD $^{\mathbf{2}}$ & $\mathbf{M D}^{\mathbf{3}}$ & Minimum & Maximum \\
\hline Age (years) & 99 & 24.9 & 6.5 & 23.0 & 16.0 & 44.0 \\
Pre-gestational weight (kg)* & 88 & 63.2 & 12.8 & 60.0 & 38.0 & 117.0 \\
Final gestational weight (kg)* & 91 & 74.1 & 13.4 & 73.0 & 47.0 & 115.4 \\
Gestational weight gain (kg)* & 86 & 11.3 & 5.9 & 10.1 & -2.0 & 31.0 \\
Gestational age (weeks) & 99 & 39.4 & 1.2 & 40.0 & 37.0 & 42.0 \\
Birth weight (g)* & 96 & 3082 & 559 & 3108 & 1500 & 4400 \\
& & & & & & \\
\hline
\end{tabular}

* It was not possible to collect data of all study participants due to the lack of some information in patient medical records and prenatal care card. ${ }^{1}$ Arithmetic mean; ${ }^{2}$ Standard Deviation; ${ }^{3}$ Median. 
The investigation of the possible influence of maternal age, number of pregnancies and weight gain during pregnancy on newborn birth weight is presented in table 2. Statistical analysis showed no relation between maternal variables and birth weight.

Regarding maternal food consumption, no correlation with maternal data was observed.

The consumption of unprocessed or minimally processed and ultra-processed foods by pregnant women in the last week of gestation is presented in table 3 .

In relation to the regular consumption of unprocessed or minimally processed foods, less than half of pregnant women regularly consumed fruits $(44.4 \%)$, raw vegetables $(28.3 \%)$ and cooked vegetables (27.3\%). About $85.9 \%$ of pregnant women regularly consumed beans and $60.6 \%$ consumed milk or yogurt. However, among ultra-processed foods, most pregnant women consumed them regularly, notably: sweets $(73.7 \%)$, soft drinks $(71.7 \%)$, sausages $(65.7 \%)$, salted crackers $(63.6 \%)$ and fried foods $(55.6 \%)$.

When analyzing the relationship between maternal food consumption and maternal age, statistical analysis showed that the consumption of cooked vegetables was higher among adult pregnant women than among adolescent pregnant women $(p=0.03)$. The consumption of ultra-processed foods was similar among adult and adolescent pregnant women $(\mathrm{p}<0.05)$ (data not shown).

The odds of newborns of presenting LBW related to maternal food consumption are presented in table 4 . The maternal consumption of sausages increased the odds of newborns of presenting LBW.

Table 5 shows the relationship between maternal food consumption in the last week of gestation and birth weight. The average consumption of sausages and sweets was significantly higher $(\mathrm{p}<0.05)$ among pregnant women whose newborns presented LBW. In addition, the average consumption of fried foods showed a strong tendency to be higher among pregnant women whose newborns presented LBW $(p=0.05)$. Among unprocessed or minimally processed foods, consumption was similar among pregnant women.

Table 2. Associations between birth weight and age, number of pregnancies and maternal weight gain.

\begin{tabular}{|c|c|c|c|c|c|}
\hline \multirow[t]{3}{*}{ Variables } & \multicolumn{4}{|c|}{ Low birth weight } & \multirow[t]{3}{*}{ p-value } \\
\hline & Yes & & No & & \\
\hline & $\mathbf{n}$ & $\%$ & $\mathbf{N}$ & $\%$ & \\
\hline \multicolumn{6}{|l|}{ Age } \\
\hline 16 H 20 years & 06 & 46.0 & 24 & 29.0 & 0.45 \\
\hline 21 H 29 years & 05 & 38.0 & 40 & 48.0 & \\
\hline $30 \mathrm{H} 44$ years & 02 & 15.0 & 19 & 23.0 & \\
\hline Total & 13 & $100.0 \%$ & 83 & $100.0 \%$ & \\
\hline \multicolumn{6}{|c|}{ Number of pregnancies } \\
\hline 01 & 06 & 46.0 & 30 & 36.0 & 0.71 \\
\hline 02 H 03 & 05 & 38.0 & 42 & 51.0 & \\
\hline$\geq 04$ & 02 & 15.0 & 11 & 13.0 & \\
\hline Total & 13 & $100.0 \%$ & 83 & $100.0 \%$ & \\
\hline \multicolumn{6}{|c|}{ Maternal weight gain } \\
\hline$<0$ & 0 & 0.0 & 0 & 0.0 & 0.40 \\
\hline 0 ト $8.0 \mathrm{~kg}$ & 05 & 42.0 & 22 & 30.0 & \\
\hline $8.0 \mathrm{H} 11.5 \mathrm{~kg}$ & 01 & 8.0 & 21 & 28.0 & \\
\hline$>11.5 \mathrm{~kg}$ & 06 & 50.0 & 31 & 42.0 & \\
\hline Total & 12 & $100.0 \%$ & 74 & $100.0 \%$ & \\
\hline
\end{tabular}

Chi-square test. 
Table 3. Consumption of foods by pregnant women in the last week.

\begin{tabular}{|c|c|c|c|c|c|c|}
\hline Food groups & $\mathbf{n}$ & $X^{1^{*}}$ & $\mathrm{SD}^{2}$ & $\mathbf{P}^{2} 5^{3}$ & $\mathrm{P}^{4} \mathbf{0}^{4}$ & $\mathrm{P} 5^{5}$ \\
\hline \multicolumn{7}{|c|}{$\begin{array}{l}\text { Unprocessed or minimally } \\
\text { processed foods }\end{array}$} \\
\hline Beans & 99 & 6.33 & 1.77 & 7.00 & 7.00 & 7.00 \\
\hline Milk or yogurt & 99 & 5.02 & 2.67 & 3.00 & 7.00 & 7.00 \\
\hline Fruits & 99 & 4.33 & 2.65 & 2.00 & 4.00 & 7.00 \\
\hline Cooked vegetables & 99 & 2.80 & 2.66 & 0.00 & 2.00 & 5.00 \\
\hline Raw vegetables & 99 & 2.67 & 2.42 & 1.00 & 2.00 & 4.00 \\
\hline \multicolumn{7}{|c|}{ Ultra-processed foods } \\
\hline Sweets & 99 & 3.30 & 2.95 & 0.00 & 2.00 & 7.00 \\
\hline Soft drinks & 99 & 3.23 & 2.99 & 0.00 & 2.00 & 7.00 \\
\hline Salted crackers & 99 & 2.77 & 2.84 & 0.00 & 2.00 & 6.00 \\
\hline Sausages & 99 & 1.48 & 1.75 & 0.00 & 1.00 & 2.00 \\
\hline Fried foods & 99 & 1.29 & 1.73 & 0.00 & 1.00 & 2.00 \\
\hline
\end{tabular}

${ }^{1}$ Arithmetic mean; ${ }^{2}$ Standard Deviation; ${ }^{3} 25^{\text {th }}$ percentile; ${ }^{4} 50$ th percentile; ${ }^{5} 75^{\text {th }}$ percentile.

*Arithmetic mean represents how many times the food group was consumed per week by pregnant women.

Table 4. Maternal food consumption and the odds of low birth weight.

\begin{tabular}{|lcc|}
\hline Food groups & $\mathbf{O R}^{\mathbf{1}}$ & \\
\hline Sausages & 1.46 & $\mathbf{9 5} \mathbf{~ C l}^{\mathbf{2}}$ \\
Fried foods & 1.38 & $1.02-2.10$ \\
Salted crackers & 1.20 & $0.96-1.98$ \\
Fruits & 1.16 & $0.92-1.57$ \\
Sweets & 1.13 & $0.87-1.54$ \\
Soft drinks & 1.13 & $0.88-1.45$ \\
Cooked vegetables & 1.08 & $0.90-1.42$ \\
Raw vegetables & 1.07 & $0.82-1.43$ \\
Beans & 0.96 & $0.79-1.45$ \\
Milk or yogurt & 0.87 & $0.67-1.38$ \\
& & $0.67-1.12$ \\
\hline
\end{tabular}

${ }^{1}$ Odds Ratio; ${ }^{2} 95 \%$ confidence interval. 
Table 5. Maternal food consumption in the last week and relationship with newborn birth weight.

\begin{tabular}{|c|c|c|c|c|c|c|c|c|c|c|c|c|c|c|c|c|c|}
\hline Food groups & \multicolumn{4}{|c|}{ Low birth weight } & \multicolumn{4}{|c|}{ Insufficient weight } & \multicolumn{4}{|c|}{ Normal weight } & \multicolumn{3}{|c|}{ Overweight* } & \multicolumn{2}{|r|}{ p-value } \\
\hline \multicolumn{18}{|c|}{$\begin{array}{l}\text { Unprocessed or minimally } \\
\text { processed foods }\end{array}$} \\
\hline Raw vegetables & 13 & 2.92 & 2.00 & 2.69 & 26 & 3.19 & 3.00 & 2.61 & 55 & 2.47 & 2.00 & 2.31 & 02 & 3.00 & 3.00 & 0.00 & 0.50 \\
\hline Cooked vegetables & 13 & 3.08 & 2.00 & 2.69 & 26 & 2.88 & 2.00 & 2.63 & 55 & 2.76 & 2.00 & 2.70 & 02 & 5.00 & 5.00 & 2.83 & 0.93 \\
\hline Fruits & 13 & 5.08 & 7.00 & 2.22 & 26 & 4.42 & 4.50 & 2.72 & 55 & 4.29 & 4.00 & 2.63 & 02 & 3.50 & 3.50 & 4.95 & 0.64 \\
\hline Beans & 13 & 6.08 & 7.00 & 2.29 & 26 & 6.73 & 7.00 & 1.37 & 55 & 6.27 & 7.00 & 1.66 & 02 & 7.00 & 7.00 & 0.00 & 0.26 \\
\hline Fried foods & 13 & 2.38 & 1.00 & 2.60 & 26 & 1.04 & 1.00 & 1.25 & 55 & 1.16 & 1.00 & 1.66 & 02 & 1.00 & 1.00 & 1.41 & 0.05 \\
\hline Sausages & 13 & $2.38^{\mathrm{a}}$ & 2.00 & 1.89 & 26 & $1.69^{a . b}$ & 1.00 & 1.74 & 55 & $1.20^{\mathrm{b}}$ & 1.00 & 1.68 & 02 & 2.50 & 2.50 & 2.12 & 0.02 \\
\hline Salted crackers & 13 & 3.31 & 3.00 & 2.90 & 26 & 2.31 & 1.00 & 2.81 & 55 & 2.87 & 2.00 & 2.88 & 02 & 5.00 & 5.00 & 2.83 & 0.48 \\
\hline Sweets & 13 & $4.92^{\mathrm{a}}$ & 7.00 & 2.87 & 26 & $3.73^{a . b}$ & 3.00 & 3.05 & 55 & $2.78^{b}$ & 2.00 & 2.79 & 02 & 3.50 & 3.50 & 4.95 & 0.04 \\
\hline Soft drinks & 13 & 4.38 & 5.00 & 2.79 & 26 & 3.46 & 2.50 & 3.05 & 55 & 2.65 & 1.00 & 2.89 & 02 & 7.00 & 7.00 & 0.00 & 0.09 \\
\hline
\end{tabular}

Kruskal-Wallis test, Dunn post-test.

${ }^{a, b}$ Different superscript letters denote significant difference.

*Data regarding dietary consumption of pregnant women who had overweight infants were not used in this statistical analysis (too few newborns in the sample).

${ }^{1}$ Arithmetic mean; ${ }^{2}$ Median; ${ }^{3}$ Standard deviation.

*Arithmetic mean of Table 5 represents how many times the food group was consumed per week by pregnant women.

\section{DISCUSSION}

The general characteristics of pregnant women in our sample (single adults, with low socioeconomic status and schooling) were similar to those found in other studies performed with pregnant women at different Basic Health Units in the Brazilian Unified Health System ${ }^{17,18,19}$.

Studies indicate that lower schooling and income levels and higher parity are positively related to the Western pattern diet, characterized by excessive consumption of ultra-processed foods ${ }^{18,20}$. However, in the present study, no association between these variables and maternal food consumption was observed.

The higher prevalence of normal delivery observed in this study can be explained by the fact that the maternity hospital where the study was developed was linked to the "Hospital Amigo da Criança" Initiative. This initiative, conceived by UNICEF, provides care that reduces invasive procedures, such as episiotomies, acceleration or labor induction and cesarean deliveries ${ }^{21}$.

Several maternal risk factors are related to LBW, such as the presence of systemic arterial hypertension, anemia, gestational diabetes, urinary tract infection and age less than 20 years and between 35 and 40 years $^{22}$. In adolescent pregnancy, there is a competition of nutrients between the growing mother and the developing fetus ${ }^{23}$. Nutrient deficiency promotes intrauterine growth restriction and consequently, LBW. Maternal aging is also related to diabetes, obesity and hypertension, morbidities that increase the risk of restriction of intrauterine growth and premature birth ${ }^{24}$.

Regarding the number of pregnancies, studies indicate that multiparous women have higher risk of LBW than primiparous. Multiparity predisposes a woman to increased risk of maternal and obstetric complications, which may trigger prematurity and neonatal intercurrences, negatively influencing birth weight ${ }^{25}$. Although the literature associates maternal age ${ }^{22,23,24}$ and number of pregnancies ${ }^{17,22}$ with LBW, this study showed no association between maternal data and newborn birth weight.

The prevalence of LBW (13.5\%) observed is higher than that found in Brazil in the same period (7.7\%), according to the Information System on Live Births ${ }^{28}$. Data show that, in Brazil, there was a reduction from $8.4 \%$ in 2012 to $7.7 \%$ in 2016. Among other Latin America countries, Honduras $(15.0 \%)$ had the highest rate of LBW in 2012, followed by Puerto Rico (12.4\%), Venezuela (10.6\%) and Colombia $(9.0 \%)$. The lowest prevalence of LBW was observed in Cuba (5.3\%), Chile (5.8\%), Peru (6.9\%), Argentina (7.0\%) and Uruguay $(8.3 \%)^{22}$. 
Literature has shown that lower risk of LBW among pregnant women with better eating habits, with predominance of consumption of unprocessed or minimally processed foods and a reduction in the consumption of ultra-processed foods, such as regular bread, pizza, sausage, among others ${ }^{7,9,29,30}$.

According to the Brazilian Ministry of Health', ultraprocessed foods tend to limit the consumption of unprocessed or minimally processed food, and, therefore, should be avoided. However, this orientation was not adopted by the pregnant women in the present study, since it was observed that, in the last week of gestation, most pregnant women regularly consumed the five ultra-processed food groups and only two groups of unprocessed or minimally processed foods.

Gomes et al. ${ }^{31}$ evaluated the eating habits of pregnant women in the second trimester of pregnancy receiving prenatal care at Basic Health Units of São Paulo, applying a questionnaire similar to that used in this study. The authors observed that $48.8 \%$ of pregnant women did not regularly consume fruits, a result inferior to that found in the present study. In addition, the authors pointed out that $45.7 \%$ of pregnant women replace main meals for snacks once or twice a week, showing the search for ultra-processed foods by this public.

The predominance of consumption of ultra-processed foods by pregnant women was also observed by other authors. The review article by Zapata et al. ${ }^{32}$ showed that pregnant women in Argentina have an excessive intake of saturated fats and sugar. Half of pregnant women also report high consumption of soft drinks. In addition, the authors verified low intake of fruits and vegetables in the maternal diet. In a study by Sandoval, Nieves and Luna ${ }^{33}$ conducted in Guanajuato, Mexico, observed that a majority of pregnant women frequently consumed sugar $(88.7 \%)$, beans $(58.5 \%)$ and milk $(54.7 \%)$ and less than half of pregnant women $(33.9 \%)$ consumed vegetables, in agreement with the results presented here.

In our study, the consumption of sausages was significantly higher among pregnant women whose newborns presented LBW. There are few studies that explain the mechanism by which sausages could favor LBW. It is known that sausages are ultra-processed foods high in nitrate and sodium and potassium nitrite, food additives used to preserve, intensify or modify their sensory properties ${ }^{30}$. It is suggested that, at high serum concentrations, nitrite ion forms an irreversible binding with blood hemoglobin, forming methemoglobin. This process hinders the transport of oxygen through fetal tissues, which may lead to fetal growth restriction, causing LBW $^{34,35}$.

Grieger, Grzeskowiak and Clifton ${ }^{29}$ showed an association between consumption of high fat and sugar foods and higher likelihood of preterm birth (adjusted OR 1.54, 95\% $\mathrm{Cl} 1.10-2.15, \mathrm{p}=0.011$ ). Maternal diet was evaluated in the 12 months prior to conception. The authors suggest that increased maternal inflammatory status would limit the transfer of nutrients to the fetus through the placenta.
Thus, the consumption of ultra-processed foods would be related to negative fetal growth outcomes, confirming the results observed here.

Hydrogenated fats, ingredients commonly used in ultra-processed foods, have been identified as responsible for an increase in the inflammatory state of the body, via stimulating the activity of prostaglandin E2 and inhibiting anti-inflammatory agents, such as prostaglandins E1 and E3. It is known that prostaglandin E2 acts at birth by inducing uterine contraction ${ }^{36,37}$, which would favor early labor, prematurity and consequently low birth weight in neonates.

Chassaing ${ }^{38}$ suggests that emulsifiers, food additives often used in the production of ultra-processed foods, stimulate the growth of pathogenic bacteria in the intestinal microbiota. These bacteria express flagellin and lipopolysaccharides, substances that activate the expression of inflammatory cytokines. Therefore, as previously explained, conditions that promote the inflammatory state in pregnant women would favor $\mathrm{LBW}^{29}$.

A woman's diet during pregnancy tends to remain similar to pre-pregnancy or to improve during the gestational period, especially due to maternal concern for adequate fetal development and growth ${ }^{31}$. Saidman et al. ${ }^{39}$ showed that $65 \%$ of pregnant women interviewed reported changes in dietary pattern during pregnancy, including increased consumption of fruits, vegetables, cereal and milk. The main motivation for these changes was to promote fetal health. Evaluating the food consumption of pregnant women through a Food Frequency Questionnaire, Fazio et al. ${ }^{40}$ concluded that there is no great variation in dietary habits during pregnancy, suggesting that diet at the end of gestation reflects the diet at the beginning of the gestational period.

This study had some limitations. First, the food consumption form was applied in the week prior to delivery, and may be influenced by physiological and / or emotional changes that occur during this period. Second, although the form is a valid tool on food consumption, being used in national surveys by the Ministry of Health, its use depends on the memory of the person being interviewed, and food consumption may be underestimated.

\section{CONCLUSION}

Most pregnant women regularly consumed unprocessed or minimally processed foods such as beans and milk or yogurt, considered markers of healthy consumption. However, among ultra-processed foods, which are considered markers of unhealthy consumption, pregnant women regularly consumed all food groups, especially sweets, soft drinks and sausages. This study showed that the maternal consumption of sausages increased the likelihood of newborns of presenting LBW.

Studies on maternal food consumption and association with LBW are still scarce, but it is essential to encourage the planning and elaboration of public interventions to reduce this outcome. Thus, further studies on maternal food consumption and its relationship with variations in birth 
weight should be carried out, which would help develop nutritional strategies more adequate for pregnant women, emphasizing maternal and child health.

\section{REFERENCES}

1. Brazil. Ministry of Health. Secretariat of Health Care. Department of Basic Attention. Food guide for the Brazilian population. 2. ed., 1. repr. Brasilia: Ministry of Health, 2014.

2. Karnopp E, Vaz J, Schafer A, Muniz L, Souza R, Santos I, et al. Food consumption of children younger than 6 years according to the degree of food processing. I Pediatr (Rio J.). 2017; 93(1): 70-78.

3. Simões B, Barreto $S$, Molina $M$, Luft $V$, Duncan B, Schmidt $M$, et al. Consumption of ultra-processed foods and socioeconomic position: a cross-sectional analysis of the Brazilian Longitudinal Study of Adult Health. Cad Saude Publica. 2018; 34(3): e00019717.

4. Monteiro C, Cannon G, Levy R, Moubarac J, Jaime P, Martins A, et al. NOVA: the star shines bright. World Nutr. 2016; 7: 28-38.

5. Pan American Health Organization. Ultra-processed food and drink products in Latin America: trends, impacto in obesity, policy implications. Washington DC: Pan American Health Organization; 2015.

6. Dos Santos Q, Sichieri R, Marchioni D, Verly Junior E. Brazilian pregnant and lactating women do not change their food intake to meet nutritional goals. BMC Pregnancy Childbirth. 2014; 14(1): 186-192.

7. Englund-Ögge L, Brantsæter A, Sengpiel V, Haugen $M$, Birgisdottir B, Myhre $R$, et al. Maternal dietary patterns and preterm delivery: results from large prospective cohort study. BMI. 2014; 348: 1446-1464.

8. Estrada-Restrepo A, Restrepo-Mesa S, Feria N, Santander F. Maternal factors associated with birth weight in term infants, Colombia, 2002-2011. Cad Saude Publica. 2016; 32(11): e00133215.

9. Martin C, Sotres-Alvarez D, Siega-Riz A. Maternal dietary patterns during the second trimester are associated with preterm birth. I Nutr. 2015; 145(8): 1857-1864.

10. Ferreira $V$, Jardim $T$, Póvoa $T$, Mendonça $K$, Nascente $F$, Carneiro $C$, et al. Birth weight and its association with blood pressure and nutritional status in adolescents. I Pediatr (Rio J.) 2018; 94(2): 184-191.

11. United Nations Children's Fund, World Health Organization. Low Birth weight: Country, regional and global estimates. UNICEF, New York, 2004.

12. Mendes C, Cacella B, Mandetta M, Balieiro M. Low birth weight in a municipality in the southeast region of Brazil. Rev Bras Enferm. 2015; 68(6): 1169-1175.

13. Tavares B, Klein C, Bloch K. Validity of informed birth weight. Study of Cardiovascular Risk in Adolescents (ERICA) - Rio de Janeiro. Rev Bras Saude Mater Infant, Recife 2017; 17(4): $705-715$.

14. World Health Organization. Women and health: today's evidence tomorrow's agenda. Geneva: World Health Organization; 2009. [internet]. [access June 28, 2018]. Available in http://www.who.int/eportuguese/publications/ Mulheres_Saude.pdf

15. Brazil. Ministry of Health. Secretariat of Health Care. Department of Basic Attention. Protocols of the Food and Nutrition Surveillance System - SISVAN in health care. Brasilia: Ministry of Health, 2008.
16. Corrêa $R$, Vencato $P$, Rockett $F$, Bosa V. Dietary patterns: are there differences between children and adolescents? Cien Saude Colet. 2017; 22(2): 553-562.

17. Capelli J, Pontes J, Pereira S, Silva A, Carmo C, Boccolini C, et al. Birth weight and factors associated with the prenatal period: a cross-sectional study in a maternity hospital of reference. Cien Saude Colet. 2014; 19(7): 2063-2072.

18. Coelho N, Cunha D, Esteves A, Lacerda E, Theme Filha M. Dietary patterns in pregnancy and birth weight. Rev Saude Publica (São Paulo). 2015; 49: 01-10.

19. Gomes K, Ferreira V, Gomes D. Quality of the diet of pregnant women in a basic health unit in Belém do Pará: a pilot study. Rev Ciencia Saude. 2015; 8(2): 54-58.

20. Castro M, Souza R, Vilela A, Kac G. Association between sociodemographics factors and dietary patterns during pregnancy. Rev Nutr. 2014; 27(2): 173-181.

21. Brazil. Ministry of Health. Ordinance No. 1.153, dated May 22, 2014. Redefines the enabling criteria of the BabyFriendly Hospital Initiative (BFHI), as a strategy to promote, protect and support breastfeeding and the integral health of children and women, within the scope of the Unified Health System. 2014. [Internet]. [access on June 12, 2018]. Available in http://bvsms.saude.gov.br/bvs/saudelegis/ gm/2014/prt1153_22_05_2014.html

22. Instituto Nacional de Salud. Protocol on Public Health Surveillance: Low birth weight at term. Bogotá; 2016. 27 p. Available in https://www.ins.gov.co/buscador-eventos/ Lineamientos/PRO\%20Bajo\%20peso\%20al\%20nacer_.pdf

23. Zapata C, Castillo C. Early weight gain of infants born to adolescent mothers. Rev Chil Nutr. 2012; 39(2): 136-142.

24. Tascón LAM, Giraldo G Daniela, Giraldo G David, Ruíz MAO, Betancourth EAV, Guatibonza MDA. Biological determinants of neonatal mortality in a population of adolescent and adult women in a hospital in Colombia. Rev Chil Obstet Ginecol. 2017; 82(4): 424-437.

25. Coutinho E, Araújo L, Pereira C, Duarte J, Nelas P, Chaves C. Factors associated with low birth weight. Rev INFAD. 2016; 1(2): 431-440.

26. Ratowiecki J, Poletta FA, Giménez LG, et al. Prevalence of low birth weight in a scenario of economic depression in Argentina. Arch Argent Pediatr. 2018; 116(5): 322-327.

27. Alonso Uría RM, Rodríguez Alonso B, Yanes Morales CD, Castillo Isaac E. Characterization of underweight neonate of adolescent mother. Rev Cubana Obstet Ginecol [Internet]. 2018; 44(1): 1-10.

28. Brazil. Ministry of Health. Health Surveillance Secretariat, Department of Health Situation Analysis. Information System on Live Births. Brasilia: Ministry of Health; 2018. [internet]. [access June 17, 2018]. Available in http://tabnet.datasus. gov.br/cgi/deftohtm.exe?sinasc/cnv/nvuf.

29. Grieger J, Grzeskowiak L, Clifton V. Preconception dietary patterns in human pregnancies are associated with preterm delivery. I Nutr. 2014; 144(7): 1075-1080.

30. Kjøllesdal M, Holmboe-Ottesen G. Dietary patterns and birth weight - a Review. AIMS Public Health. 2014; 3(4): 211-225.

31. Gomes C, Malta M, Martiniano A, Bonifácio L, Carvalhaes $M$. Eating habits of pregnant and non-pregnant women: are there differences? Rev Bras Ginecol Obstet. 2015; 37(7): 325-332.

32. Zapata ME, Rovirosa A, Pueyrredón P, Weill F, Chamorro V, Carella $B$, et al. Nutritional status of pregnant and lactating women from Argentina. Diaeta (B. Aires). 2016; 34(155): 
33-40.

33. Sandoval $K V$, Nieves ER, Luna MA. Personalized diet effect in pregnant obese or overweight women. Rev Chil Nutr. 2016; 43(3): 233-246.

34. Oliveira J, Silva UR, Pastore V, Azevedo E, Campos G, Silva FCG, et al. Spectrophotometric determination of nitrite in cured meat products. Rev Bras Hig Sanid Anim. 2017; 11(1): 19-31.

35. Hentges D, Zart N, Marmitt LG, Oliveira EC, Scherer Adami $F$. Nitrate and nitrate concentrations in sausages. Rev Bras Promoç Saude. 2016; 29(1): 27-33.

36. Baek H, Hwang HR, Park H, Kwon A, Qadir AS, Ko S, et al. TNF- $\alpha$ Upregulates Sclerostin Expression in Obese Mice Fed a High-Fat Diet. J Cell Physiol 2013; 229(5): 640-650.

37. Rocha DM, Bressan J, Hermsdorff HH. The role of dietary fatty acid intake in inflammatory gene expression: a critical review. Med J (São Paulo). 2017; 135(2): 157-168.

38. Chassaing B. Involvement of food additives in intestinal inflammation and metabolic syndrome in mice. Med Sci (Paris). 2015; 31(6-7): 586-588.

39. Saidman N, Raele MG, Basile M, Barreto L, Mackinonn MJ, Poy MS et al. Knowledge, interests and beliefs on food and nutrition in pregnant women. Diaeta (B. Aires). 2012; 30(139): 18-27.

40. Fazio $E$, Nomura $R$, Dias $M$, Zugaib M. Dietary intake of pregnant women and maternal weight gain after nutritional counseling. Rev Bras Ginecol Obstet (São Paulo). 2011; 33(2): 87-92. 